\title{
Comparative study of Mg/Al- and Zn/Al-layered double hydroxide-perindopril erbumine nanocomposites for inhibition of angiotensin-converting enzyme
}

\author{
This article was published in the following Dove Press journal: \\ International Journal of Nanomedicine \\ 2 August 2012 \\ Number of times this article has been viewed
}

\author{
Samer Hasan Hussein \\ Al Ali' \\ Mothanna Al-Qubaisi² \\ Mohd Zobir Hussein ${ }^{1,3}$ \\ Maznah Ismail 2,4 \\ Zulkarnain Zainal ${ }^{1}$ \\ Muhammad Nazrul Hakim ${ }^{5}$ \\ 'Department of Chemistry, \\ Faculty of Science, ${ }^{2}$ Laboratory \\ of Molecular Biomedicine, Institute \\ of Bioscience, ${ }^{3}$ Advanced Materials \\ and Nanotechnology Laboratory, \\ Institute of Advanced Technology, \\ ${ }^{4}$ Department of Nutrition and Health \\ Science, ${ }^{5}$ Department of Biomedical \\ Science, Faculty of Medicine and \\ Health Science, Universiti Putra \\ Malaysia, Selangor, Malaysia
}

\begin{abstract}
The intercalation of a drug active, perindopril, into $\mathrm{Mg} / \mathrm{Al}$-layered double hydroxide for the formation of a new nanocomposite, PMAE, was accomplished using a simple ion exchange technique. A relatively high loading percentage of perindopril of about $36.5 \%$ $(\mathrm{w} / \mathrm{w})$ indicates that intercalation of the active took place in the $\mathrm{Mg} / \mathrm{Al}$ inorganic interlayer. Intercalation was further supported by Fourier transform infrared spectroscopy, and thermal analysis shows markedly enhanced thermal stability of the active. The release of perindopril from the nanocomposite occurred in a controlled manner governed by pseudo-second order kinetics. MTT assay showed no cytotoxicity effects from either $\mathrm{Mg} / \mathrm{Al}$-layered double hydroxide or its nanocomposite, PMAE. Mg/Al-layered double hydroxide showed angiotensin-converting enzyme inhibitory activity, with 5.6\% inhibition after 90 minutes of incubation. On incubation of angiotensin-converting enzyme with $0.5 \mu \mathrm{g} / \mathrm{mL}$ of the PMAE nanocomposite, inhibition of the enzyme increased from $56.6 \%$ to $70.6 \%$ at 30 and 90 minutes, respectively. These results are comparable with data reported in the literature for $\mathrm{Zn} / \mathrm{Al}$-perindopril.

Keywords: magnesium, aluminum, layered double hydroxide, perindopril erbumine, ion exchange, angiotensin-converting enzyme, Chang cells line
\end{abstract}

\section{Introduction}

Brucite refers to the neutral layers of magnesium hydroxide, discovered in 1824 . The magnesium ion is centered to six octahedrally arranged hydroxide ions. Each hydroxide is bonded to three magnesium atoms. ${ }^{1}$ Hydrotalcite is derived from the brucite structure, and can be described by the formula, $\mathrm{Mg}_{6} \mathrm{Al}_{2}\left(\mathrm{CO}_{3}\right)(\mathrm{OH})_{16} \cdot 4 \mathrm{H}_{2} \mathrm{O}$, formed by isomorphous substitution of the $\mathrm{Mg}^{2+}$ with $\mathrm{Al}^{3+}$ and forming layers with a positive charge. The carbonate anion is the counter-balanced charge of the layers. Layered double hydroxides, ie, hydrotalcite-like materials, take the general formula $\left[\mathrm{M}_{1-\mathrm{x}}^{2+} \mathrm{M}_{\mathrm{x}}^{3+}(\mathrm{OH})_{2}\right]^{x+}\left(\mathrm{A}^{\mathrm{m}-}\right)_{x / m} \cdot n \mathrm{H}_{2} \mathrm{O}$, where $\mathrm{M}^{2+}$ is a divalent cation, $\mathrm{M}^{3+}$ is a trivalent cation, and $\mathrm{A}^{\mathrm{m}-}$ is an exchangeable anion with charge $(\mathrm{m}){ }^{2,3} \mathrm{Mg} / \mathrm{Al}$-layered double hydroxides have attracted considerable attention as drug delivery materials due to their advantages of easy preparation in the laboratory, good biocompatibility, ${ }^{4}$ low cytotoxicity, ${ }^{5,6}$ and full protection of the intercalated drugs. ${ }^{7}$ Because of these advantages, many pharmaceutically active compounds have been intercalated in order to prolong their action. These include methotrexate, ${ }^{8,9}$ captopril, ${ }^{10}$ the anti-inflammatory drugs, fenbufen, diclofenac, ibuprofen, and camptothecin, ${ }^{5,11-13}$ as well as the statin agents, pravastatin and fluvastatin. ${ }^{14}$
Correspondence: Mohd Zobir Hussein Department of Chemistry, Faculty of Science, Universiti Putra Malaysia, 43400 Serdang, Selangor, Malaysia Tel +60389466801

Fax +60389435380

Email mzobir@science.upm.my submit your manuscript | www.dovepress.com

Dovepress

http://dx.doi.org// 0.2147/IJN.S32267 
Here we describe our work on the intercalation of perindopril erbumine, an antihypertensive angiotensinconverting enzyme (ACE) inhibitor, into $\mathrm{Mg} / \mathrm{Al}$-layered double hydroxide by the ion-exchange technique. Our work was focused on the structure of perindopril between the $\mathrm{Mg} / \mathrm{Al}$-layered double hydroxide interlayer, its thermal and controlled release properties, and the effect of the resulting nanocomposite and the $\mathrm{Mg} / \mathrm{Al}$-layered double hydroxide on ACE. We compared our results with those reported in the literature for $\mathrm{Zn} / \mathrm{Al}$-perindopril.

\section{Materials and methods Materials}

Perindopril erbumine $\left(\mathrm{C}_{23} \mathrm{H}_{43} \mathrm{~N}_{3} \mathrm{O}_{5}\right.$, molecular weight 441.6) of $99.79 \%$ purity was purchased from CCM Duopharma (Klang, Malaysia) and used as received. Other materials, including $\mathrm{Mg}\left(\mathrm{NO}_{3}\right)_{2} \cdot 6 \mathrm{H}_{2} \mathrm{O}, \mathrm{Al}\left(\mathrm{NO}_{3}\right)_{3} \cdot 9 \mathrm{H}_{2} \mathrm{O}, \mathrm{NaOH}, \mathrm{ACE}$, and hippuryl-histidyl-leucine were purchased from Sigma (St Louis, MO) and used as received. Deionized water was used in all experiments.

\section{Synthesis of perindopril erbumine-Mg/Al nanocomposite}

The precursor, a $\mathrm{Mg} / \mathrm{Al}$-layered double hydroxide in nitrate form, was synthesized by a procedure similar to that reported previously. ${ }^{15}$ A solution of magnesium nitrate $0.025 \mathrm{~mol} / \mathrm{L}$ and aluminum nitrate $0.0125 \mathrm{~mol} / \mathrm{L}$ was prepared in deionized water. A solution of sodium hydroxide at a concentration of $2 \mathrm{~mol} / \mathrm{L}$ was added dropwise to the mother liquor solution with vigorous stirring under a nitrogen atmosphere until a $\mathrm{pH}$ of 10 was reached.

Perindopril-Mg/Al-layered double hydroxide was prepared using an ion-exchange method. A fresh layered double hydroxide- $\mathrm{NO}_{3}$ precursor was dropped into a $0.3 \mathrm{~mol} / \mathrm{L}$ solution of perindopril with vigorous stirring in a nitrogen atmosphere. The $\mathrm{pH}$ of the mixture was 10.0 , and it was kept for 18 hours at $70^{\circ} \mathrm{C}$. The precipitate was washed and centrifuged three times. The product was denoted as PMAE.

\section{Controlled-release study}

Release of perindopril from the PMAE nanocomposite into the medium of phosphate-buffered solution at $\mathrm{pH} 7.4$ and $4.8^{10,16,17}$ was performed by adding about $85 \mathrm{mg}$ of PMAE into $250 \mathrm{~mL}$ of the buffer solutions. The accumulated amount of perindopril released into the solution was measured at regular intervals using an ultraviolet-visible spectrophotometer at $215 \mathrm{~nm}$. To compare the release rate of perindopril from PMAE with that from the physical mixture of perindopril and pristine $\mathrm{Mg} / \mathrm{Al}$-layered double hydroxide (prepared for this purpose), ${ }^{18} 0.6 \mathrm{mg}$ of the physical mixture of perindopril $(0.22 \mathrm{mg})$ and the pristine layered double hydroxide $(0.38 \mathrm{mg})$ was also used to perform the same perindopril release experiments.

\section{MTT cytotoxicity and in vitro antihypertensive assay}

Chang cells from a human liver cells line, were used in this study. The cells were seeded into 96-well plates and kept at $5 \% \mathrm{CO}_{2}$ and $37^{\circ} \mathrm{C}$ for 24 hours. When the cells had grown to $90 \%$ confluence, they were treated with the perindopril erbumine, PMAE nanocomposite, and Mg/Al-layered double hydroxide formulations at $0.156,0.313,0.625,1.25,2.5,5.0$, and $10 \mu \mathrm{g} / \mathrm{mL}$. After 24 hours of incubation, the cells in each well were treated with $20 \mu \mathrm{L}$ of MTT solution $(5 \mathrm{mg} / \mathrm{mL})$ and incubated for 4 hours. The microplates were turned swiftly to discard the medium, and the formazan precipitate was dissolved in $10 \%$ sodium dodecyl sulfate in dimethyl sulfoxide containing $0.6 \%$ acetic acid. The microplates were then gently shaken in the dark for 30 minutes, and absorbance was measured at $570 \mathrm{~nm}$ and $630 \mathrm{~nm}$ (background) using a microtiter plate reader. All experiments were carried out in triplicate. $\mathrm{The} \mathrm{IC}_{50}$ was generated from the dose-response curves for the cells line.

The in vitro antihypertensive activity of free perindopril, intercalated perindopril in layered double hydroxide (ie, PMAE), and Mg/Al-layered double hydroxide was assayed by measuring ACE inhibition activity using the method of Cushman and Cheung (1971). In vitro ACE inhibition activity was quantified by converting hippuryl-histidyl-leucine to hippuric acid via ACE in the presence of the inhibitor; absorbance was measured at $228 \mathrm{~nm}$. Any reduction in absorbance is proportional to the inhibition exerted by the inhibitor being assayed. Perindopril and PMAE $(0.5 \mu \mathrm{g} / \mathrm{mL})$ were preincubated with $\mathrm{ACE}$ for 20 minutes in a $25 \mu \mathrm{L}$ volume in $1 \times$ buffer $(\mathrm{pH} 8.3)$, then mixed with $10 \mu \mathrm{L}$ of $3.5 \mathrm{mM}$ hippuryl-histidyl-leucine. The assay mixture was incubated at $37^{\circ} \mathrm{C}$ for 30,60 , and 90 minutes. The reaction was stopped by adding $50 \mu \mathrm{L}$ of $3 \mathrm{~mol} / \mathrm{L} \mathrm{HCl}$. The hippuric acid formed by ACE was extracted with $1 \mathrm{~mL}$ of ethyl acetate. The solvent was removed by heat evaporation and redissolved in deionized water. The amount of hippuric acid was measured using a fluorescent plate reactor at $228 \mathrm{~nm}$.

\section{Characterization}

Powder X-ray diffraction patterns were recorded in the range from $2^{\circ}-70^{\circ}$ on a Shimadzu diffractometer, XRD-6000, 
using $\mathrm{CuK}_{\alpha}$ radiation $(\lambda=1.5418 \AA)$ at $30 \mathrm{kV}$ and $30 \mathrm{~mA}$, with a dwell time of 0.5 degrees per minute. Fourier transform infrared (FTIR) spectra of the materials were recorded over the range $400-4000 \mathrm{~cm}^{-1}$ on a Thermo Nicolet Nexus FTIR (Smart Orbit model) with $4 \mathrm{~cm}^{-1}$ resolution, using the $\mathrm{KBr}$ disc method with approximately $1 \%$ of the sample in $200 \mathrm{mg}$ of spectroscopic grade potassium bromide, and pellets made by pressing at 10 tonnes.

The chemical composition of the samples was analyzed for magnesium and aluminum ions by inductively coupled plasma atomic emission spectrometry using a Perkin-Elmer spectrophotometer model Optima 2000DV (Perkin-Elmer, Boston, MA) under standard conditions. A CHNS-932 LECO instrument was used for carbon, hydrogen, nitrogen, and sulfur analyses. Thermogravimetric and differential thermogravimetric analyses were carried out using a Mettler Toledo instrument with a heating rate of $10^{\circ} \mathrm{C}$ per minute in the range of $20^{\circ} \mathrm{C}-1000^{\circ} \mathrm{C}$ under a nitrogen atmosphere (nitrogen flow rate $50 \mathrm{~mL}$ per minute). Surface characterization of the material was carried out using a nitrogen gas adsorptiondesorption technique at $77 \mathrm{~K}$, with a Micromeritics ASAP 2000 instrument. A field emission scanning electron microscope (Nova ${ }^{\circledR}$ Nanosem 230 model, Hillsboro, OR) was used to determine the surface morphology of the samples. Ultraviolet-visible spectra were measured to determine optical properties, and the controlled release study was accomplished using a Perkin Elmer ultraviolet-visible spectrophotometer (Lambda 35).

\section{Results and discussion Powder X-ray diffraction}

Powder X-ray diffraction is a technique used to investigate the phase of crystalline materials present in a sample, which involves interaction between X-rays with crystal to form diffraction patterns, from which much information can be derived. With the help of other methods, such as molecular calculation, the intercalation of anions into the inorganic layered double hydroxide interlayers and their orientation between the interlayers can also be studied.

Powder X-ray diffraction patterns of perindopril erbumine and the product of its reaction with fresh $\mathrm{Mg} / \mathrm{Al}-\mathrm{NO}_{3}$ double hydroxide for the formation of a nanocomposite, PMAE, are shown in Figure 1A. The (001) reflections of PMAE appeared at a low $2 \theta$ angle, ie, $3.86^{\circ}, 8.66^{\circ}$, and $6.91^{\circ}$ for 003, 006, and 009 reflections, respectively. As reported in the literature, 003, 006, and 009 reflections for the precursor $\mathrm{Mg} / \mathrm{Al}-\mathrm{NO}_{3}$ layered double hydroxide appear at $10.71^{\circ}$, $20.45^{\circ}$, and $34.8^{\circ}$, respectively. ${ }^{19}$ Shifting of the reflection

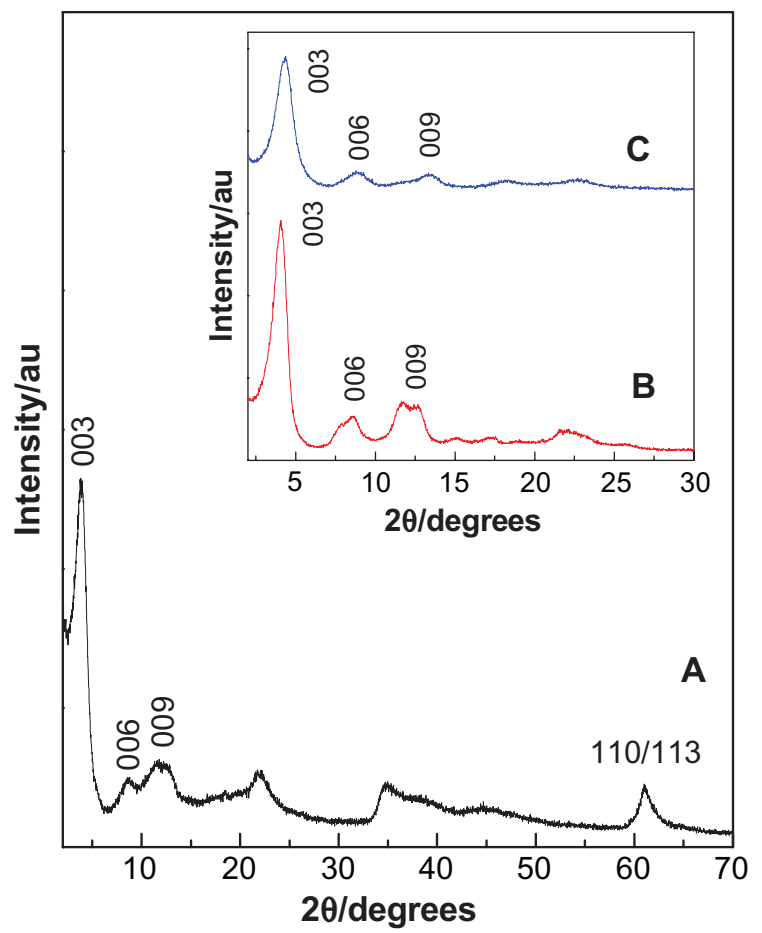

Figure I Powder X-ray diffraction patterns for the nanocomposite, PMAE (A). Inset shows the $\mathrm{X}$-ray diffraction patterns for the nanocomposites PZAE (B) and PZAC (C). ${ }^{21}$

Abbreviations: PMAE, perindopril intercalated into $\mathrm{Mg} / \mathrm{Al}$ by ion-exchange; $\mathrm{PZAE}$, perindopril intercalated into $\mathrm{Zn} / \mathrm{Al}$ by ion-exchange; PZAC, perindopril intercalated into $\mathrm{Zn} / \mathrm{Al}$ by coprecipitation method.

toward low $2 \theta$ for PMAE is indicative of intercalation of perindopril into the interlayer galleries of layered double hydroxide by anion exchange with nitrate ions. The (110) at $61.2^{\circ}$, corresponding to $1.53 \AA$ for the $\mathrm{Mg} / \mathrm{Al}-\mathrm{NO}_{3}$ sample, did not shift after the intercalation process, indicating that intercalation of perindopril did not change the structure of the layer, but only changed the interlayer spacing. ${ }^{20}$ Furthermore, a broad peak at $11.46^{\circ}$ corresponds to the (003) reflection of $\mathrm{Mg} / \mathrm{Al}-\mathrm{NO}_{3}$ layered double hydroxide, while this peak is overlapped with the (009) reflection in PMAE. This result indicates the presence of remaining unreacted $\mathrm{Mg} / \mathrm{Al}-\mathrm{NO}_{3}$ layered double hydroxide phase mixed with the intercalated material.

The inset in Figure $1 \mathrm{~B}$ and $\mathrm{C}$ shows the intercalation of perindopril erbumine into $\mathrm{Zn} / \mathrm{Al}$-layered double hydroxide accomplished by the ion-exchange method (PZAE) and direct method (PZAC), respectively. ${ }^{21}$ It can be seen that the $\mathrm{d}$-spacing $\left(\mathrm{d}_{003}\right)$ of the PMAE and PZAE nanocomposites is $22.85 \AA$ and $21.70 \AA$, respectively. This similarity indicates that the orientation of perindopril between the layers is similar and arranged as an alternating bilayer. The slight discrepancy in the $\mathrm{d}_{003}$ value between them is probably mainly due to the content of water in the interlayer 
galleries and the presence of nitrate ions in the interlayer region. ${ }^{22}$

The lattice parameters, $a$ and $c$, of PMAE were calculated using $d$ values of 003,006 , and 009 reflections, where $c=1 / 3\left(3 \mathrm{~d}_{003}+6 \mathrm{~d}_{006}+9 \mathrm{~d}_{009}\right)$, and 110 reflection for parameter $a$, where $a=2 \mathrm{~d}_{110}$, and is shown in Table 1. The $a$ and $c$ values are $3.02 \AA$ and $64.00 \AA$, respectively.

From Table 1, similarity in the $c$ value between PMAE and PZAE suggests that the perindopril anions should be arranged in the interlayer space in a similar fashion and that a small difference between them can be related to the conditions of preparation, or more probably the amount of water, as indicated in Table 1. The correlation between the $\mathrm{M}^{2+} / \mathrm{Al}^{3+}$ ratio and $\mathrm{d}_{003}$ for PMAE and PZAE is in good agreement with that reported previously in the literature. ${ }^{23}$

\section{Molecular structure and spatial orientation of intercalated perindopril}

Figure 2A shows the three-dimensional molecular size of perindopril obtained using Chemoffice software (Cambridge, MA). The long and short axes (the $\mathrm{x}$ axis and $y$ axis, respectively) and molecular thickness ( $\mathrm{z}$ axis) of perindopril were calculated, giving values of $13 \AA, 8.4 \AA$, and $12.6 \AA$, respectively. The $\mathrm{X}$-ray diffraction pattern shows that the average basal spacing, $d$, of the PMAE nanocomposite was $21.98 \AA$ (average for five harmonics). The thickness of the $\mathrm{Mg} / \mathrm{Al}-\mathrm{NO}_{3}$ layered double hydroxide layer was $4.8 \AA,{ }^{24}$ therefore the gallery height of layered double hydroxide after the intercalation processes was $17.18 \AA(21.98-4.80 \AA)$. The gallery height of PMAE was $17.18 \AA$, which is much larger than the value of the long axis $(13 \AA)$ and slightly similar to double the short axis $(16.80 \AA)$. This indicates that the perindopril anions are accommodated as an alternate bilayer, as illustrated in Figure 2B.

\section{Infrared spectroscopy}

FTIR is a technique used for identification of functional groups and chemical bonds that are present in a molecule, interpreted from the observed infrared absorption spectrum.

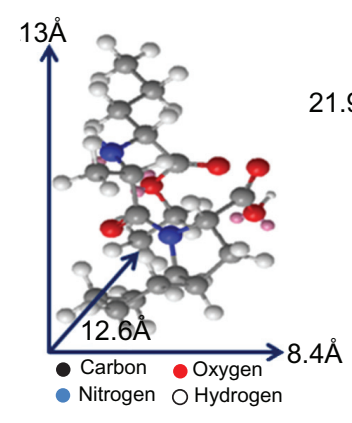

A

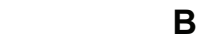

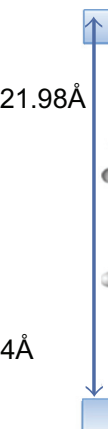

Figure 2 Three-dimension structure of perindopril erbumine (A) and molecular structural models of perindopril intercalated between interlayers of Mg/AI-LDH (B). Abbreviations: $\mathrm{Mg}$, magnesium; $\mathrm{Al}$, aluminum; LDH, layered double hydroxide.

Each functional group has its own specific wavenumber/s and absorption characteristics, from which the functional group present in the sample can be inferred. Therefore, this technique can be used as supporting data which complement other techniques to indicate that intercalation instead of adsorption has taken place.

The FTIR spectrum of perindopril erbumine is shown in Figure 3A. As shown in the figure, the band at $2929 \mathrm{~cm}^{-1}$ is due to $\mathrm{CH}$ in $\mathrm{NH}-\mathrm{CH}$-propyl, while the band at $2851 \mathrm{~cm}^{-1}$ can be attributed to $\mathrm{CH}$ in $\mathrm{CH}_{3}-\mathrm{CH}-\mathrm{NH}$. The band recorded at $1154 \mathrm{~cm}^{-1}$ is related to the symmetric stretching of $\mathrm{C}-\mathrm{N}-\mathrm{C} .{ }^{25}$ The band at $1745 \mathrm{~cm}^{-1}$ is due to $\mathrm{C}=\mathrm{O}$ in the ester group. The carboxylic group shows peaks at $1731 \mathrm{~cm}^{-1}$ that are related to $v(\mathrm{C}=\mathrm{O})$ stretching.

As can be observed in the FTIR spectrum of PMAE (Figure 3B), a broad band at $3452 \mathrm{~cm}^{-1}$ could be attributed to $\mathrm{OH}$ stretching vibration due to the presence of a hydroxyl group in the layered double hydroxide and/or a physically adsorbed water molecule. A band at $1612 \mathrm{~cm}^{-1}$ is due to the asymmetric vibration $\mathrm{COO}^{-}$mode and another band at $1384 \mathrm{~cm}^{-1}$ is due to the symmetric vibration of $\mathrm{COO}^{-26}$ and also due to co-intercalated nitrate anions which may not be completely removed from the interlayers during the intercalation process. The presence of "new" carboxylate bands confirm that the perindopril species intercalated into the layered

Table I XRD data of diffraction peaks and the lattice parameters of PMAE, PZAE and PZAC nanocomposites

\begin{tabular}{llllllllll}
\hline Samples & $\mathbf{d}_{003}$ & $\mathbf{d}_{006}$ & $\mathbf{d}_{009}$ & $\mathbf{d}_{110}$ & $\boldsymbol{a}$ & $\mathbf{c}$ & $\mathbf{M}^{2+} / \mathbf{A l}^{3+}$ & $\boldsymbol{x}$ & Empirical formula $^{(\boldsymbol{A})}$ \\
\hline PMAE & 22.83 & 10.20 & 6.90 & 1.51 & 3.02 & 64.00 & 2.04 & 0.33 & {$\left[\mathrm{Mg}_{0.67} \mathrm{Al}_{0.33}\left(\mathrm{OH}_{2}\right]\left(\mathrm{PE}^{-}\right)_{0.21}\left(\mathrm{NO}_{3}^{-}\right)_{0.12} \cdot 1.4 \mathrm{H}_{2} \mathrm{O}\right.$} \\
PZAE* & 21.70 & 10.60 & 7.08 & 1.53 & 3.07 & 65.60 & 3.48 & 0.22 & {$\left[\mathrm{Zn}_{0.78} \mathrm{Al}_{0.22}\left(\mathrm{OH}_{2}\right]\left(\mathrm{PE}^{-}\right)_{0.19}\left(\mathrm{NO}_{3}^{-}\right)_{0.03} \cdot 0.4 \mathrm{H}_{2} \mathrm{O}\right.$} \\
PZAC* & 19.90 & 9.96 & 6.67 & 1.54 & 3.07 & 59.80 & 2.60 & 0.28 & {$\left[\mathrm{Zn}_{0.72} \mathrm{Al}_{0.28}\left(\mathrm{OH}_{2}\right]\left(\mathrm{PE}^{-}\right)_{0.177}\left(\mathrm{NO}_{3}^{-}\right)_{0.103} \cdot 0.91 \mathrm{H}_{2} \mathrm{O}\right.$} \\
\hline
\end{tabular}

Note: *Data from reference. ${ }^{21}$

Abbreviations: $\mathrm{Mg}$, magnesium; $\mathrm{Al}$, aluminum; $\mathrm{Zn}$, zinc; $\mathrm{NO}_{3}$, nitrate; $\mathrm{PE}$, perindopril erbumine; $\mathrm{OH}$, hydroxide; PMAE, perindopril intercalated into $\mathrm{Mg} / \mathrm{Al}$ by ion-exchange; $\mathrm{PZAE}$, perindopril intercalated into Zn/Al by ion-exchange; PZAC, perindopril intercalated into Zn/Al by coprecipitation method. 


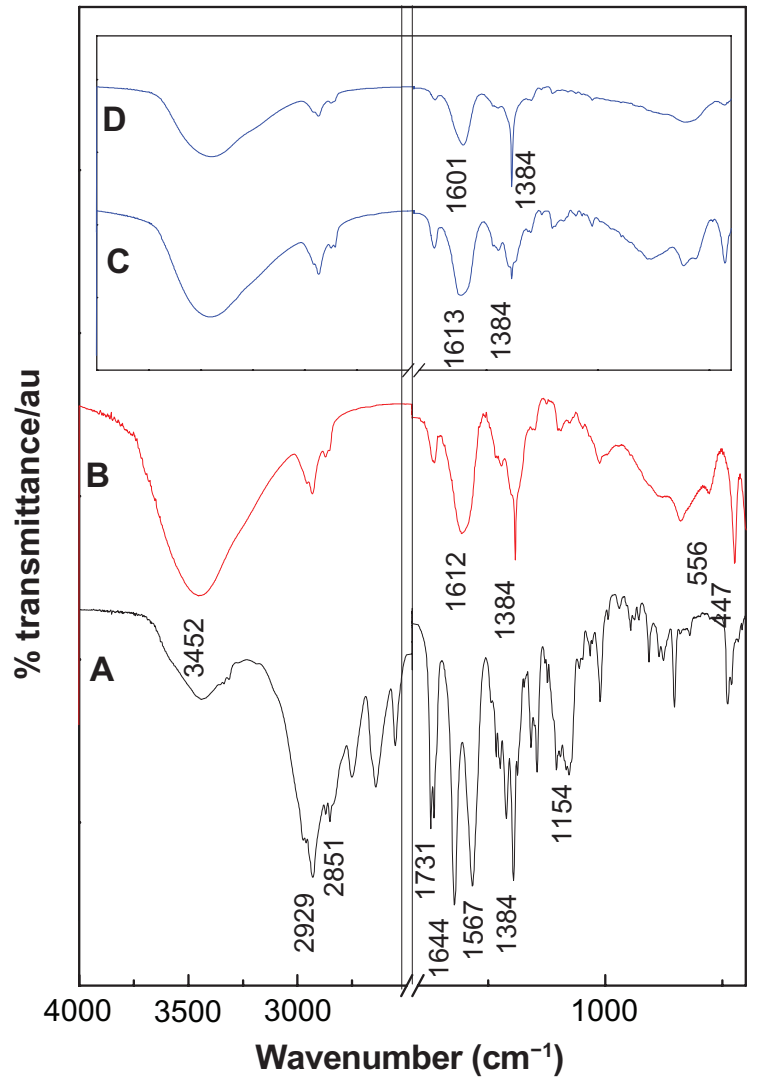

Figure 3 Fourier transform infrared spectra of perindopril erbumine (A) and PMAE nanocomposite (B). Inset shows the Fourier transform infrared spectra of the nanocomposites PZAE (C) and PZAC (D). ${ }^{21}$

Abbreviations: PMAE, perindopril intercalated into $\mathrm{Mg} / \mathrm{Al}$ by ion-exchange; $\mathrm{PZAE}$, perindopril intercalated into $\mathrm{Zn} / \mathrm{Al}$ by ion-exchange; PZAC, perindopril intercalated into $\mathrm{Zn} / \mathrm{Al}$ by coprecipitation method.

double hydroxide layers is in an anionic form. The bands recorded at $1730 \mathrm{~cm}^{-1}$ are due to the presence of perindopril adsorbed on the surface in a neutral form. Other bands in the low range of wavenumbers $\left(556 \mathrm{~cm}^{-1}\right.$ and $\left.447 \mathrm{~cm}^{-1}\right)$ can be ascribed to translational modes of $\mathrm{Mg} / \mathrm{Al}-\mathrm{OH} .^{3,27}$

Comparing the FTIR spectra of PMAE with the PZAE and PZAC nanocomposites obtained in our previous work, ${ }^{21}$ they show no significant difference, indicating that intercalation of perindopril into $\mathrm{Mg} / \mathrm{Al}$-layered double hydroxide has taken place without much change in the structure of perindopril in any of the nanocomposites, which is in good agreement with the powder X-ray diffraction results.

\section{Elemental analysis}

Elemental analysis was conducted to determine the organic and inorganic composition of PMAE. As expected, the PMAE nanocomposite contained both organic and inorganic constituents. This indicates that intercalation had occurred, in which perindopril was intercalated into the $\mathrm{Mg} / \mathrm{Al}$-layered double hydroxide inorganic interlayers.
The percentage of magnesium and aluminum ions and $\mathrm{Mg}^{2+} / \mathrm{Al}^{3+}$ molar ratio in the PMAE nanocomposite was obtained using the inductively coupled plasma technique, with values of $13.10 \%, 7.20 \%$, and $2.04 \%$, respectively. As a result of the elemental chemical analysis, the carbon, nitrogen, and perindopril loading between the layers was determined to be $22.46 \%, 3.46 \%$, and $36.50 \%$, respectively. Loading of perindopril into the $\mathrm{Zn} / \mathrm{Al}$ systems, namely PZAE and PZAC, was $37.20 \%$ and $33.40 \%$, respectively. ${ }^{21}$ The FTIR spectrum shows a strong band at $1384 \mathrm{~cm}^{-1}$ due to the presence of trace amounts of a nitrate group in the interlamellar spacing of layered double hydroxide. Therefore, the empirical formula for the PMAE nanocomposite can be proposed as $\left[\mathrm{Mg}_{0.67} \mathrm{Al}_{0.33}(\mathrm{OH})_{2}\right]\left(\mathrm{PE}^{-}\right)_{0.21}\left(\mathrm{NO}_{3}^{-}\right)_{0.12} \cdot 1.4 \mathrm{H}_{2} \mathrm{O}$.

\section{Thermal analysis}

Thermal analysis is a technique used to measure the percentage of weight loss of a sample as a function of heating temperature, or time under a controlled environment. It is usually used to indicate the decomposition of a sample, from which it relates to thermal stability at selected temperatures, usually between $25^{\circ} \mathrm{C}$ and $1000^{\circ} \mathrm{C}$. In a selected environment, a thermal analysis can also be used to study the oxidation or dehydration behavior of a sample.

The thermal behavior of perindopril erbumine and PMAE was examined using thermogravimetric analysis and differential thermogravimetric analysis (Figure 4). For perindopril erbumine (Figure 4A), two main thermal events were clearly observed. The first one occurred in the region of $90^{\circ} \mathrm{C}-192^{\circ} \mathrm{C}$, attributable to melting of perindopril erbumine, corresponding to a sharp peak at $157^{\circ} \mathrm{C}$ with $24.1 \%$ weight loss. The second stage at $192^{\circ} \mathrm{C}-312^{\circ} \mathrm{C}$ is due to decomposition and subtle combustion of perindopril erbumine, ${ }^{28}$ corresponding to a strong peak at $276^{\circ} \mathrm{C}$ with $81.2 \%$ weight loss. Figure 4B shows that the thermal decomposition of PMAE progresses through four major stages of weight loss, occurring at temperature maxima of $74^{\circ} \mathrm{C}, 238^{\circ} \mathrm{C}, 357^{\circ} \mathrm{C}$, and $669^{\circ} \mathrm{C}$ with weight losses of $10.0 \%, 5.2 \%, 43.2 \%$, and $3.5 \%$, respectively. The first and second stages of weight loss in the range of $28^{\circ} \mathrm{C}-278^{\circ} \mathrm{C}$ are due to the removal of water physisorbed on the external surface of the layered double hydroxide as well as structured water. ${ }^{29}$ The third stage of weight loss is usually overlapped ${ }^{30}$ and can be attributed to dehydroxylation of the metal hydroxide layers and combustion of perindopril anions at $357^{\circ} \mathrm{C}$. The final stage of weight loss is related to the formation of spinel phase, $\mathrm{MgAl}_{2} \mathrm{O}_{4}{ }^{31}$ Increasing the decomposition of perindopril from $276^{\circ} \mathrm{C}$ (for free perindopril) to $357^{\circ} \mathrm{C}$ (for perindopril intercalated 

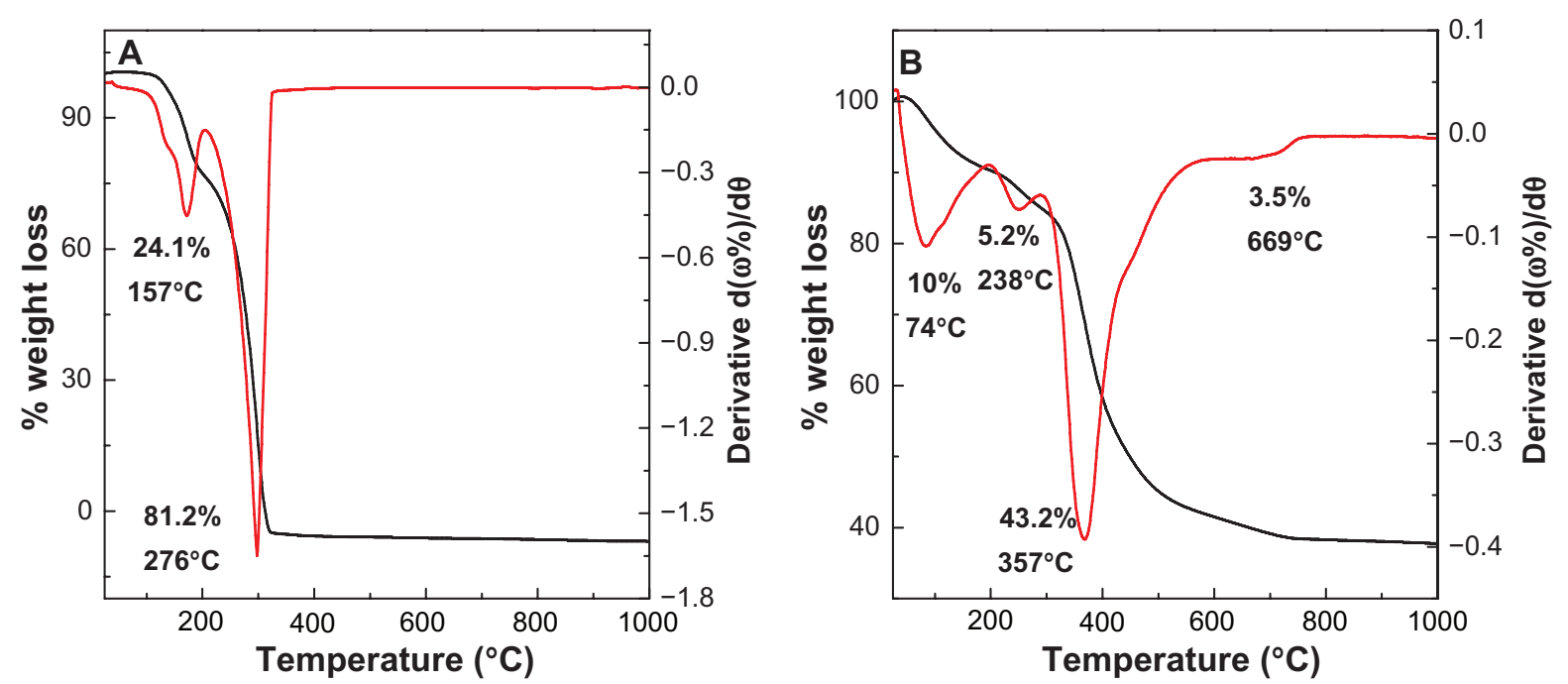

Figure 4 Thermogravimetric and differential thermogravimetric analysis of perindopril (A) and PMAE nanocomposite (B). Abbreviation: PMAE, perindopril intercalated into Mg/Al by ion-exchange.

into the nanocomposite) indicates better thermal stability of perindopril in the intercalated form, PMAE, than the free compound. This presumably is due to electrostatic attraction between the negatively charged functional group of perindopril and the positively charged $\mathrm{Mg} / \mathrm{Al}$ interlayers.

A similar phenomenon was observed in the case of perindopril intercalated into $\mathrm{Zn} / \mathrm{Al}$-layered double hydroxide to form PZAE and PZAC nanocomposites. Table 2 shows the weight loss percentages for the three types of nanocomposites. The thermal properties of perindopril in these nanocomposites were different, with a maximum temperature corresponding to weight loss in the third stage for PMAE of $357^{\circ} \mathrm{C}$, compared with $346^{\circ} \mathrm{C}$ and $300^{\circ} \mathrm{C}$ for PZAE and PZAC, respectively. This indicates that the thermal stability of the nanocomposites can be arranged as PMAE $>$ PZAE $>$ PZAC.

\section{Surface properties}

Figure 5A shows the adsorption-desorption isotherms for $\mathrm{Mg} / \mathrm{Al}$-layered double hydroxide and the PMAE nanocomposite. As shown in the figure, both isotherms are Type IV by International Union of Pure and Applied Chemistry classification, indicating a mesopore-type material. ${ }^{32}$ The adsorbate uptake of $\mathrm{Mg} / \mathrm{Al}$-layered double hydroxide was slow in the relative pressure range of $0.0-0.8$, after which rapid adsorption can be observed, with an optimum uptake of about $8 \mathrm{~cm}^{3} / \mathrm{g}$, indicating a low capacity for uptake of nitrogen gas. However, for the PMAE nanocomposite, adsorbate uptake is slow until relative pressures of 0.4. A further increase of the relative pressure to $>0.4$ resulted in rapid adsorption of the absorbent, and reached an optimum at $9.7 \mathrm{~cm}^{3} / \mathrm{g}$. The desorption branch of the hysteresis loop for $\mathrm{Mg} / \mathrm{Al}$-layered double hydroxide was different from that of PMAE. For the former, it shows the H1 type (open-ended cylindrical pore) compared with the $\mathrm{H} 2$ type for the latter, PMAE (with open slit-shaped capillaries). ${ }^{33}$ As a result of nitrogen adsorption, the surface area of the materials was determined by the Brunauer, Emmet, and Teller (BET) method to increase from $3 \mathrm{~m}^{2} / \mathrm{g}$ for Mg/Al-layered double hydroxide to $11 \mathrm{~m}^{2} / \mathrm{g}$ for the PMAE nanocomposite (Table 3 ). This is due to a change in the pore texture as a result of formation of the nanocomposite compound.

Figure 5B shows plots of the Barret-Joyner-Halenda (BJH) desorption pore size distribution for $\mathrm{Mg} / \mathrm{Al}$-layered

Table 2 Shows the weight loss percentages for the three types of the nanocomposites; PMAE, PZAE and PZAC

\begin{tabular}{|c|c|c|c|c|c|c|c|c|c|c|c|c|c|}
\hline \multirow[t]{2}{*}{ Samples } & \multicolumn{3}{|c|}{ First weight loss (\%) } & \multicolumn{3}{|c|}{ Second weight loss (\%) } & \multicolumn{3}{|c|}{ Third weight loss (\%) } & \multicolumn{3}{|c|}{ Last weight loss (\%) } & \multirow{2}{*}{$\begin{array}{l}\text { Total weight } \\
\text { loss (\%) }\end{array}$} \\
\hline & $\begin{array}{l}\text { Onset } \\
\left({ }^{\circ} \mathrm{C}\right)\end{array}$ & $\begin{array}{l}\text { Offset } \\
\left({ }^{\circ} \mathrm{C}\right)\end{array}$ & $\begin{array}{l}W_{t} \\
\text { loss (\%) }\end{array}$ & $\begin{array}{l}\text { Onset } \\
\left({ }^{\circ} \mathrm{C}\right)\end{array}$ & $\begin{array}{l}\text { Offset } \\
\left({ }^{\circ} \mathrm{C}\right)\end{array}$ & $\begin{array}{l}W_{t} \\
\text { loss (\%) }\end{array}$ & $\begin{array}{l}\text { Onset } \\
\left({ }^{\circ} \mathrm{C}\right)\end{array}$ & $\begin{array}{l}\text { Offset } \\
\left({ }^{\circ} \mathrm{C}\right)\end{array}$ & $\begin{array}{l}W_{t} \\
\text { loss (\%) }\end{array}$ & $\begin{array}{l}\text { Onset } \\
\left({ }^{\circ} \mathrm{C}\right)\end{array}$ & $\begin{array}{l}\text { Offset } \\
\left({ }^{\circ} \mathrm{C}\right)\end{array}$ & $\begin{array}{l}W_{t} \\
\text { loss (\%) }\end{array}$ & \\
\hline PMAE & 28 & 188 & 10.0 & 188 & 278 & 5.2 & 280 & 562 & 43.2 & 562 & 725 & 3.5 & 61.9 \\
\hline PZAE* & 34 & 118 & 4.2 & 119 & 258 & 13.6 & 257 & 487 & 31.1 & 591 & 858 & 7.0 & 55.9 \\
\hline PZAC* & 38 & 137 & 6.2 & 136 & 244 & 8.7 & 246 & 499 & 31.8 & 559 & 927 & 12.6 & 59.3 \\
\hline
\end{tabular}

Note: *Data from reference. ${ }^{21}$

Abbreviations: PMAE, perindopril intercalated into Mg/AI by ion-exchange; PZAE, perindopril intercalated into Zn/Al by ion-exchange; PZAC, perindopril intercalated into Zn/Al by coprecipitation method. 

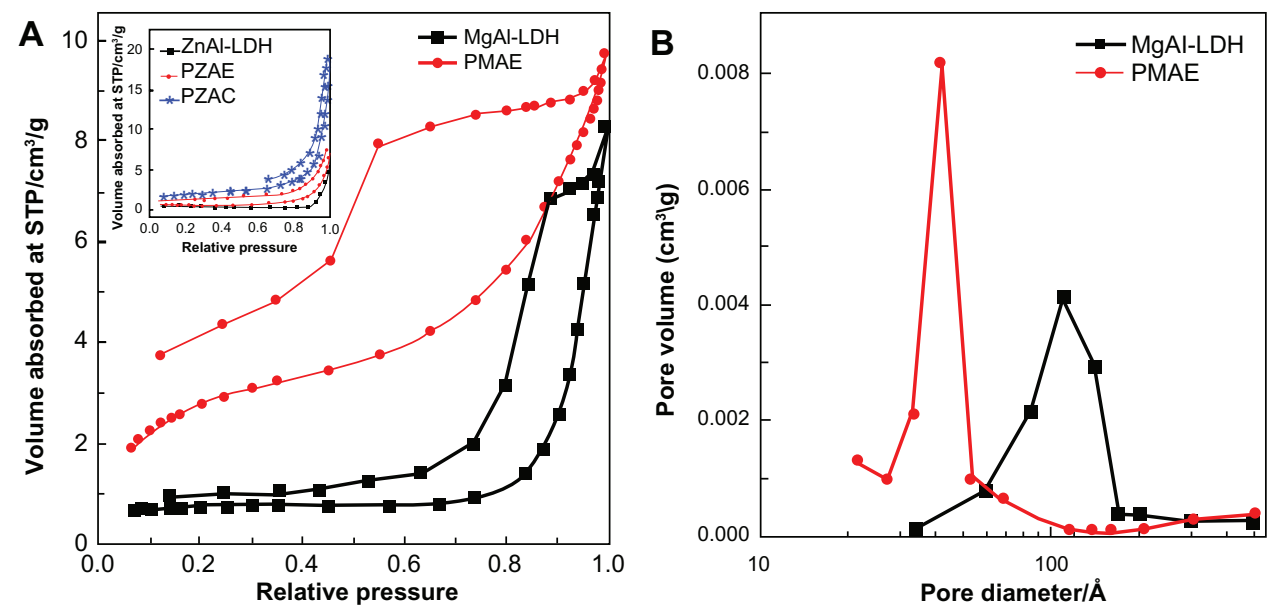

Figure 5 Adsorption-desorption isotherms (A) and Barret-Joyner-Halenda pore size distributions (B) for Mg/Al-LDH and its nanocomposite with perindopril erbumine, PMAE. Inset in (A) shows the adsorption-desorption isotherms for PZAE, PZAC, and ZnAI-LDH. ${ }^{21}$

Abbreviations: $M g$, magnesium; Al, aluminum; LDH, layered double hydroxide; PMAE, perindopril intercalated into Mg/AI by ion-exchange; PZAE, perindopril intercalated into $\mathrm{Zn} / \mathrm{Al}$ by ion-exchange; PZAC, perindopril intercalated into $\mathrm{Zn} / \mathrm{Al}$ by coprecipitation method; Zn, zinc; STP, standard temperature pressure.

double hydroxide and PMAE. As shown in the figure, a single-peaked pore size distribution is observed for $\mathrm{Mg} / \mathrm{Al}$-layered double hydroxide, centered at around $42 \AA$. On the other hand, the PMAE sample shows a single peak at $112 \AA$. Due to the intercalation process, the BJH pore volume increased from 0.01 for $\mathrm{Mg} / \mathrm{Al}$-layered double hydroxide to $0.02 \mathrm{~cm}^{3} / \mathrm{g}$ for PMAE, whereas the $\mathrm{BJH}$ average pore diameter decreased from $108 \AA$ to $40 \AA$ for Mg/Al-layered double hydroxide to PMAE, respectively (Table 3 ).

The inset in Figure 5A shows the adsorption-desorption isotherms for PZAE, PZAC, and Zn/Al-layered double hydroxide. ${ }^{21}$ The isotherms are Type IV by International Union of Pure and Applied Chemistry classification, similar to those of $\mathrm{Mg} / \mathrm{Al}$-layered double hydroxide and PMAE. The desorption branch of the hysteresis loop for $\mathrm{Zn} / \mathrm{Al}$-layered double hydroxide, PZAE, and PZAC are different from that of PMAE and $\mathrm{Mg} / \mathrm{Al}$-layered double hydroxide, in which the former shows the $\mathrm{H} 3$ type (slit-shaped pores). Table 3 shows the Brunauer, Emmett, and Teller specific surface area for

Table 3 Surface properties for the nanomaterials

\begin{tabular}{llll}
\hline Samples & $\begin{array}{l}\text { BET surface } \\
\text { area }\left(\mathbf{m}^{2} / \mathbf{g}\right)\end{array}$ & $\begin{array}{l}\text { BJH pore } \\
\text { volume }\left(\mathrm{cm}^{3} / \mathbf{g}\right)\end{array}$ & $\begin{array}{l}\text { BJH pore } \\
\text { diameter }(\mathbf{A})\end{array}$ \\
\hline Mg/Al-LDH & 3 & 0.010 & 108 \\
PMAE & II & 0.020 & 40 \\
Zn/Al-LDH* & 1 & 0.008 & 243 \\
PZAE* & 2 & 0.009 & 135 \\
PZAC* & 7 & 0.025 & 157 \\
\hline
\end{tabular}

Note: *Data from reference. ${ }^{21}$

Abbreviations: $\mathrm{Zn}$, zinc; $\mathrm{Al}$, aluminum; $\mathrm{Mg}$, magnesium; $\mathrm{LDH}$, layered double hydroxide; PMAE, perindopril intercalated into $\mathrm{Mg} / \mathrm{Al}$ by ion-exchange; PZAE, perindopril intercalated into $\mathrm{Zn} / \mathrm{Al}$ by ion-exchange; PZAC, perindopril intercalated into $\mathrm{Zn} / \mathrm{Al}$ by coprecipitation method; BJH, Barret-Joyner-Halenda; BET, BrunauerEmmett-Teller.
PMAE, Mg/Al-layered double hydroxide, Zn/Al-layered double hydroxide, PZAE, and PZAC. The surface area for PMAE is $11 \mathrm{~m}^{2} / \mathrm{g}$, which is higher than for PZAE and PZAC, at $2 \mathrm{~m}^{2} / \mathrm{g}$ and $7 \mathrm{~m}^{2} / \mathrm{g}$, respectively.

The surface morphologies of $\mathrm{Mg} / \mathrm{Al}$-layered double hydroxide and PMAE are shown in Figure 6. The micrographs in Figure 6A and D were obtained using a field emission scanning electron microscope at $10,000 \times$, Figure $6 \mathrm{~B}$ and $\mathrm{E}$ at $25,000 \times$, and Figure $6 \mathrm{C}$ and $\mathrm{F}$ at $50,000 \times$ magnifications. Figure $6 \mathrm{~A}-\mathrm{C}$ shows a flake-like porous structure for $\mathrm{Mg} / \mathrm{Al}$-layered double hydroxide. However, the morphology changed to a compact nonporous structure (Figure 6D-F) when the PMAE nanocomposite was formed. This morphology is slightly different from that of PZAE, PZAC, and Zn/Al-layered double hydroxide. ${ }^{21}$

\section{Sustained-release study}

The release properties of perindopril were investigated by adding the intercalated compound into phosphate-buffered solution at $\mathrm{pH} 7.4$ and 4.8. Figures $7 \mathrm{C}$ and D show the release profiles of PMAE at $\mathrm{pH} 4.8$ and 7.4, respectively. The inset shows release profiles of a physical mixture of perindopril with $\mathrm{Mg} / \mathrm{Al}$-layered double hydroxide into phosphate-buffered solution at 4.8 (Figure 7A and B). The physical mixture shows that the release profile of perindopril is rapid and complete during the initial 10 minutes. This result indicates that the interaction between the contents of the physical mixture is almost negligible. On the other hand, the release rate of perindopril from PMAE was obviously very much lower, indicating that the PMAE nanocomposite could potentially be used as a controlled-release formulation. 

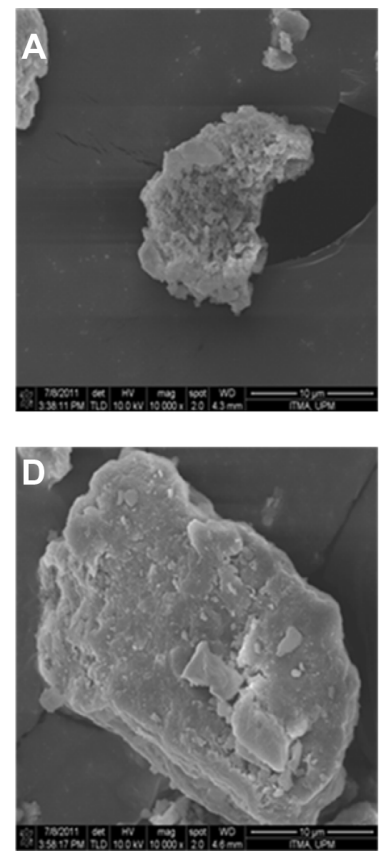
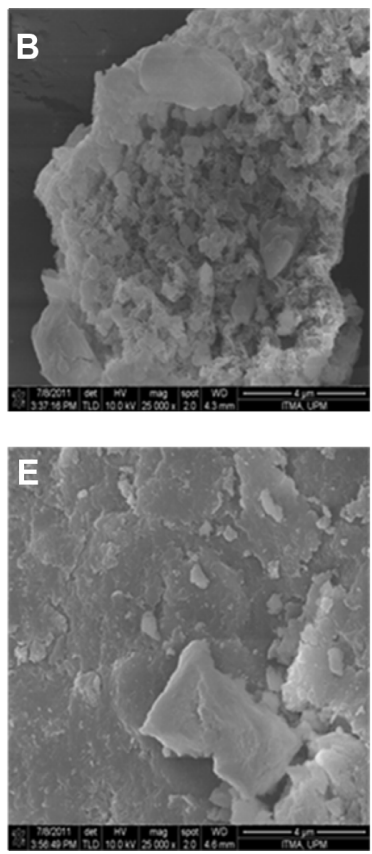
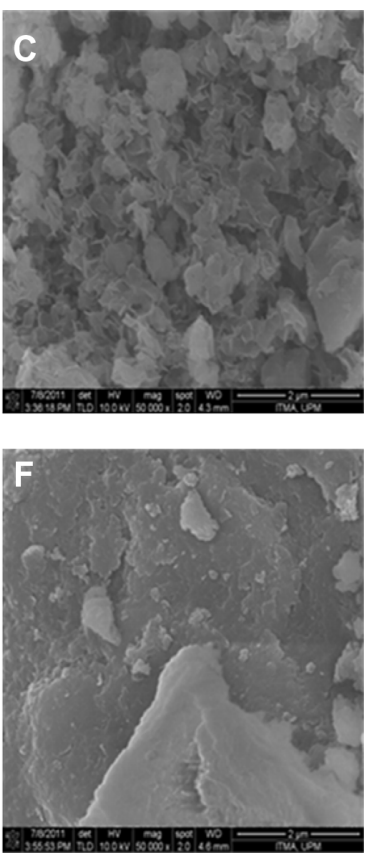

Figure 6 Field emission scanning electron microscopic images of $\mathrm{Mg} / \mathrm{Al}-\mathrm{LDH}(\mathbf{A}-\mathbf{C})$ and PMAE (D-F).

Abbreviations: PMAE, perindopril intercalated into Mg/Al by ion-exchange; Mg, magnesium; Al, aluminum; LDH, layered double hydroxide.

This may be due to electrostatic attraction between the interlayers of Mg/Al-layered double hydroxide and perindopril anions that were intercalated in between the inorganic interlayers.

The release behavior at $\mathrm{pH} 4.8$ (Figure 7C) was very fast for the first 20 minutes, which can be attributed to partial dissolution of the $\mathrm{Mg} / \mathrm{Al}$-layered double hydroxide layer in an acidic environment. ${ }^{34,35}$ Thereafter, a slower release step characterized by a release percentage of $100 \%$ after 1000 minutes can be observed. This slow release step was due to the exchange process between perindopril anions in interlayer and anions in the buffer solution. ${ }^{12,35,36}$ At $\mathrm{pH} 7.4$, (Figure 7II), the release of perindopril is slower than at $\mathrm{pH} 4.8$, with $100 \%$ release by 5000 minutes. The slow and sustained release process may also be due to the ion-exchange process between perindopril and anions in the buffer solution. ${ }^{12,35,36}$

The release profiles of PMAE and PZAE (described in our previous work, in which perindopril was intercalated into $\mathrm{Zn} /$ Al-layered double hydroxide using the ion-exchange method) were compared. ${ }^{21}$ The orientation of perindopril in both nanocomposites was bilayered, but the release rate from PMAE
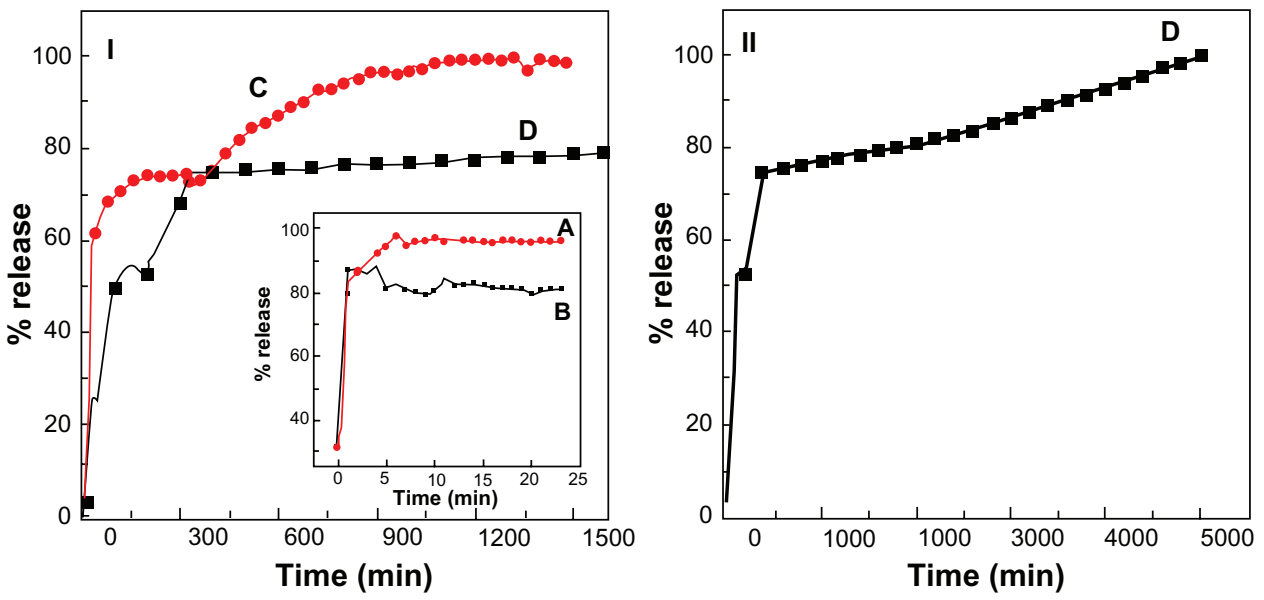

Figure 7 (I) Release profiles of perindopril from the PMAE nanocomposite at $\mathrm{pH} 4.8$ (C) and pH 7.4 (D) up to I500 minutes, (II) release profiles of perindopril up to 5000 minutes at $\mathrm{pH}$ 7.4. Inset shows the release profiles of perindopril from its physical mixture of perindopril with $\mathrm{Mg} / \mathrm{Al}-\mathrm{LDH}$ at $\mathrm{pH} 4.8(\mathbf{A})$ and $\mathrm{pH} 7.4(\mathbf{B})$.

Abbreviations: PMAE, perindopril intercalated into $\mathrm{Mg} / \mathrm{Al}$ by ion-exchange; $\mathrm{Mg}$, magnesium; $\mathrm{Al}$, aluminum; $\mathrm{LDH}$, layered double hydroxide. 
was found to be very much lower than that from PZAE. The time taken to complete release was 5000 minutes in the former compared with $70 \%$ release within 1000 minutes for the latter at $\mathrm{pH}$ 7.4. This is due to the different charge density between the anions and inorganic interlayers. When the charge density was increased, the electrostatic interaction between the layered double hydroxide lattice and interlayer anions was increased, resulting in a slower release rate, as observed in the PMAE sample.

\section{Release kinetics of perindopril from PMAE}

The release behavior of perindopril from the PMAE nanocomposite may be described using different kinetic models. The results of kinetic release from perindopril were analyzed using pseudo-first order (equation 1), ${ }^{37}$ pseudo-second order (equation 2) ) $^{38}$ and parabolic diffusion (equation 3 ) models: $:^{20}$

$$
\begin{gathered}
\ln \left(\mathrm{q}_{\mathrm{e}}-\mathrm{q}_{\mathrm{t}}\right)=\ln \mathrm{q}_{\mathrm{e}}-\mathrm{k}_{1} \mathrm{t} \\
\mathrm{t} / \mathrm{q}_{\mathrm{t}}=1 / \mathrm{k}_{2} \mathrm{q}_{\mathrm{e}}^{2}+\mathrm{t} / \mathrm{q}_{\mathrm{e}} \\
\left(1-\mathrm{M}_{\mathrm{t}} / \mathrm{M}_{\mathrm{o}}\right) / \mathrm{t}=\mathrm{k} \mathrm{t}^{-0.5}+\mathrm{b}
\end{gathered}
$$

where $\mathrm{M}_{\mathrm{o}}$ and $\mathrm{M}_{\mathrm{t}}$ are drug content remaining in the layered double hydroxide at release time 0 and $t$, respectively, $q_{e}$ and $q_{t}$ are the equilibrium release amount, the release amount at time $t$, respectively, and $\mathrm{k}$ is the corresponding release rate constant.

Using the three kinetic models mentioned above for the kinetic release data, it was found that the pseudo-second order model was more satisfactory compared with other models in this work for describing the release kinetics of perindopril from the PMAE nanocomposite. Figure 8 shows plots of the kinetic models at $\mathrm{pH} 4.8$, with a correlation coefficient $\left(\mathrm{R}^{2}\right)$ and $\mathrm{k}$ value of 0.9953 and $6.3 \times 10^{-5} \mathrm{mg}$ per minute, respectively. At $\mathrm{pH} 7.4$, the corresponding values were 0.9901 and $3.17 \times 10^{-5} \mathrm{mg}$ per minute, respectively (Table 4). The kinetic results obtained in this work are very similar to a kinetic study of the release of camptothecin from $\mathrm{Mg} / \mathrm{Al}$-layered double hydroxide ${ }^{37}$ and also similar to perindopril erbumine intercalated into $\mathrm{Zn} / \mathrm{Al}$-layered double hydroxide by the ion-exchange and coprecipitation methods. ${ }^{21}$ It is worth mentioning that the release of perindopril from $\mathrm{Zn} / \mathrm{Al}$-LDH-intercalated perindopril obtained either by the ion exchange-method (PZAE) or the direct method (PZAC) followed the pseudo-second order model. ${ }^{21}$

\section{Cytotoxicity assay and in vitro antihypertensive activity}

The effect of perindopril erbumine, PMAE, and $\mathrm{Mg} / \mathrm{Al}$-layered double hydroxide on cell viability was
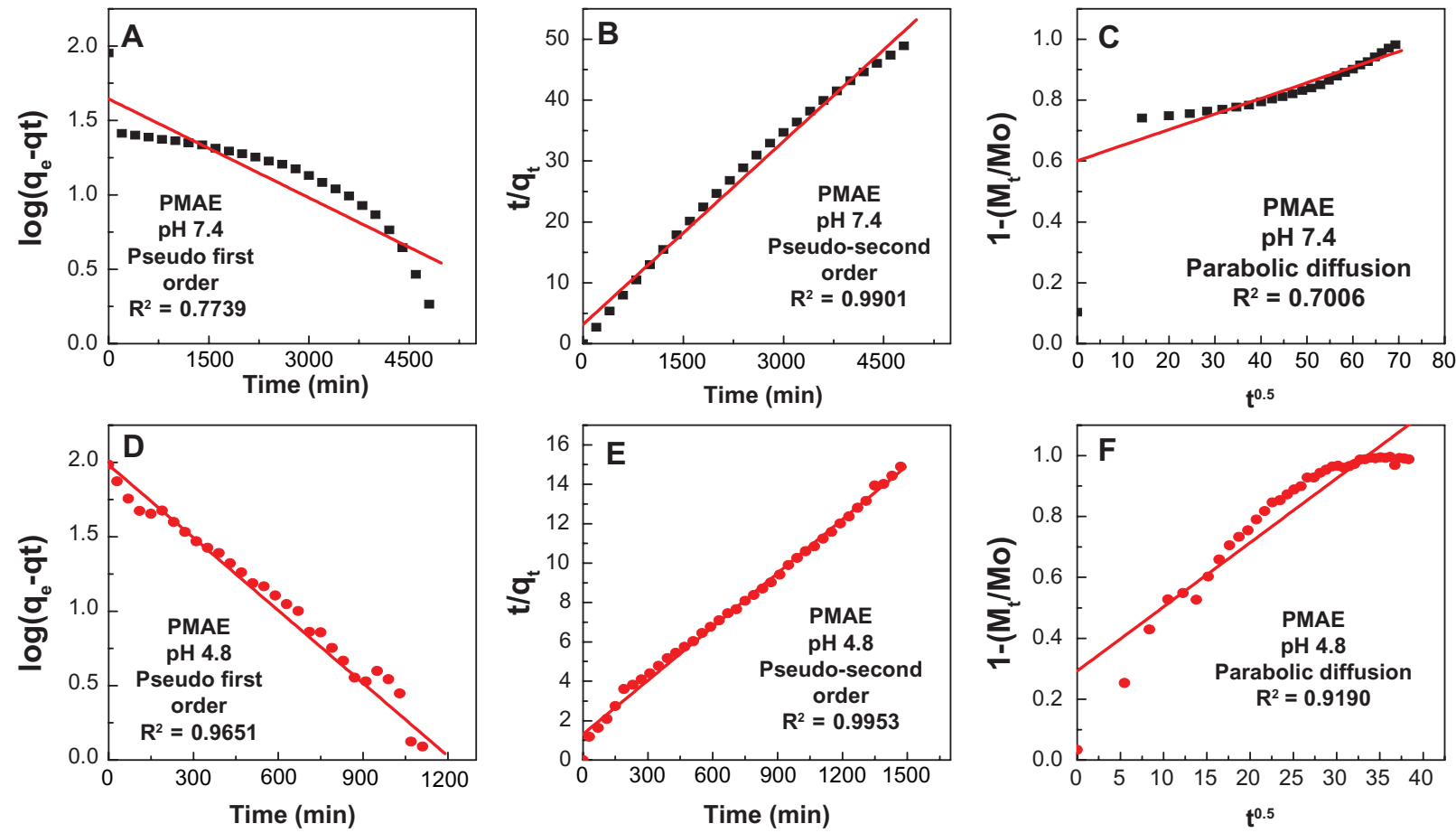

Figure 8 Fitting the data of perindopril release from PMAE at $7.4(\mathbf{A}-\mathbf{C})$ and at 4.8 (D-F). Abbreviation: PMAE, perindopril intercalated into $\mathrm{Mg} / \mathrm{Al}$ by ion-exchange. 
Table 4 Correlation coefficient $\left(R^{2}\right)$, rate constants $(K)$ and half time $\left(t_{1 / 2}\right)$ obtained by fitting the perindopril release data from PMAE nanocomposite into solutions at $\mathrm{pH} 4.8$ and 7.4

\begin{tabular}{|c|c|c|c|c|c|c|}
\hline \multirow[t]{2}{*}{$\mathrm{pH}$} & \multirow[t]{2}{*}{ Saturation release (\%) } & \multicolumn{3}{|c|}{$\mathbf{R}^{2}$} & \multicolumn{2}{|c|}{ Pseudo-second order } \\
\hline & & $\begin{array}{l}\text { Pseudo-first } \\
\text { order }\end{array}$ & $\begin{array}{l}\text { Parabolic diffusion } \\
\text { model }\end{array}$ & $\begin{array}{l}\text { Pseudo-second } \\
\text { order }\end{array}$ & $\begin{array}{l}\text { Rate constant, } \mathrm{K} \\
(\mathrm{mg} / \mathrm{min}) \times 10^{-5}\end{array}$ & $t_{1 / 2}(\min )$ \\
\hline 7.4 & 100 & 0.7739 & 0.7006 & 0.9901 & 3.17 & 315 \\
\hline 4.8 & 100 & 0.9651 & 0.9190 & 0.9953 & 6.30 & 145 \\
\hline
\end{tabular}

Abbreviation: PMAE, perindopril intercalated into Mg/Al by ion-exchange.

investigated in this work using a Chang cells line at various concentrations of $0.156,0.313,0.625,1.25,2.5,5.0$, and $10.0 \mu \mathrm{g} / \mathrm{mL}$, with 24 hours of incubation time. As shown in Figure 9, perindopril erbumine did not show any effect on the viability of Chang cells. Interestingly, PMAE and $\mathrm{Mg} / \mathrm{Al}$-layered double hydroxide also showed no toxic effect on Chang cells, at least up to a concentration of $10.0 \mu \mathrm{g} / \mathrm{mL}$. These results are consistent with those of a previous study showing no cytotoxicity of $\mathrm{Mg} / \mathrm{Al}$-layered double hydroxide on Vero3 cells line. ${ }^{39}$

ACE inhibitors are widely used clinically as antihypertensive agents. Perindopril erbumine is a prodrug ester of perindoprilat, an ACE inhibitor. The present study is the first report on the ACE inhibition activity of free $\mathrm{Mg}$ / Al-layered double hydroxide versus perindopril erbumine intercalated into $\mathrm{Mg} / \mathrm{Al}$. ACE inhibition activity was determined in vitro by monitoring transformation of the hippuryl-histidyl-leucine substrate to hippuric acid. Figure 10 and Table 5 show the effect of perindopril erbumine, PMAE, and Mg/Al-layered double hydroxide

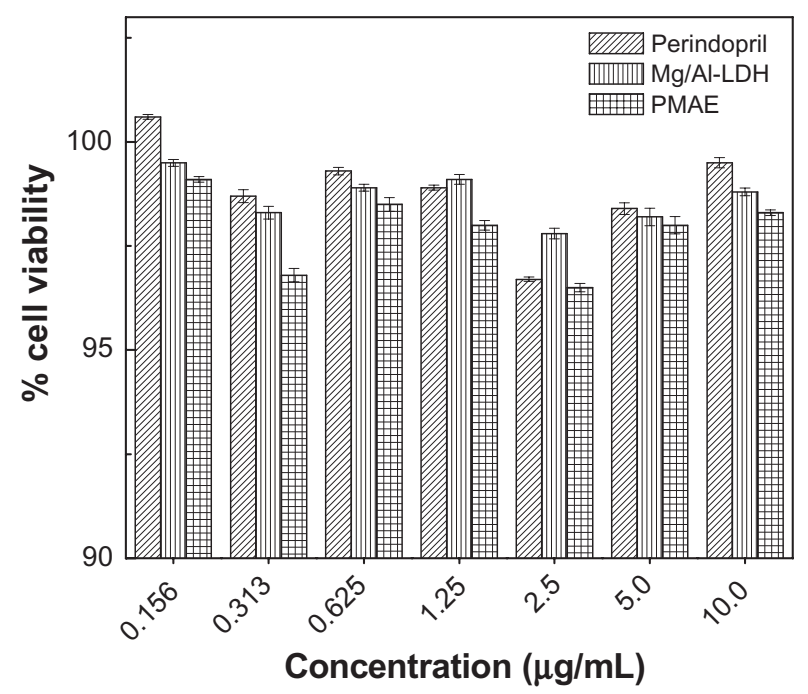

Figure 9 MTT assays of normal Chang liver cells after 24 hours of treatment with perindopril erbumine, PMAE, and Mg/AI-LDH.

Abbreviations: PMAE, perindopril intercalated into $\mathrm{Mg} / \mathrm{Al}$ by ion-exchange; $\mathrm{Mg}$, magnesium; Al, aluminum; LDH, layered double hydroxide. on ACE. Mg/Al-layered double hydroxide shows ACE inhibition activity, and a 5.6\% decrease in ACE activity was observed at 90 minutes of incubation. Comparing this result with our previous work, Zn/Al-layered double hydroxide did not show any effect on ACE. ${ }^{21} \mathrm{ACE}$ inhibition in the PMAE formulation was time-dependent, that may be attributable to a high level of perindopril erbumine release from the PMAE nanocomposite. However, following incubation of ACE with $0.5 \mu \mathrm{g} / \mathrm{mL}$ of PMAE, ACE inhibition increased from $56.6 \%$ to $70.6 \%$ at 30 and 90 minutes of incubation, respectively, as compared with the untreated control.

Comparing the inhibitory activity of PMAE with that of PZAE and PZAC nanocomposites, PMAE shows the strongest inhibition of $70.6 \%$ after 90 minutes, compared with $70.1 \%$ and $55.4 \%$ inhibition for PZAE and PZAC, respectively. This is due to the slow release properties as well as the cation effect of magnesium. ${ }^{40}$

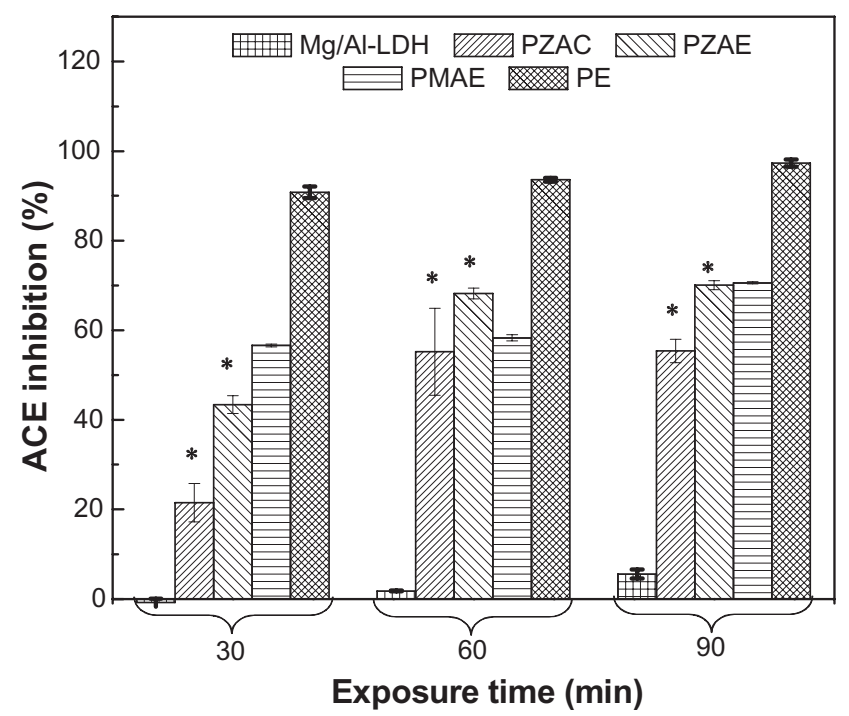

Figure 10 ACE inhibition (\%) for free perindopril and intercalated perindopril, PMAE, PZAE, PZAC, and Mg/AI-LDH at exposure times of 30,60 , and 90 minutes. Abbreviations: $\mathrm{Mg}$, magnesium; $\mathrm{Al}$, aluminum; $\mathrm{LDH}$, layered double hydroxide; PMAE, perindopril intercalated into $\mathrm{Mg} / \mathrm{Al}$ by ion-exchange; $\mathrm{PZAE}$, perindopril intercalated into $\mathrm{Zn} / \mathrm{Al}$ by ion-exchange; PZAC, perindopril intercalated into $\mathrm{Zn} / \mathrm{Al}$ by coprecipitation method; Zn, zinc. 
Table 5 ACE activity for perindopril erbumine, PMAE, PZAE, PZAC and $\mathrm{Mg} / \mathrm{Al}-\mathrm{LDH}$ at different exposure times

\begin{tabular}{llllll}
\hline $\begin{array}{l}\text { Exposure time } \\
\text { (minutes) }\end{array}$ & $\begin{array}{l}\text { Perindopril } \\
\text { erbumine }\end{array}$ & PMAE & $\begin{array}{l}\text { MgAl- } \\
\text { LDH }\end{array}$ & PZAE* $^{*}$ & PZAC $^{*}$ \\
\hline 30 & 90.8 & 56.6 & -0.8 & 43.4 & 21.5 \\
60 & 93.6 & 58.3 & 1.80 & 68.2 & 55.2 \\
90 & 97.3 & 70.6 & 5.60 & 70.1 & 55.4 \\
\hline
\end{tabular}

Note: *Data obtained from reference. ${ }^{21}$

Abbreviations: ACE, Angiotensin-converting enzyme; $\mathrm{Mg}$, magnesium; $\mathrm{Al}$, aluminum; $\mathrm{LDH}$, layered double hydroxide; PMAE, perindopril intercalated into $\mathrm{Mg} / \mathrm{Al}$ by ion-exchange; $\mathrm{PZAE}$, perindopril intercalated into $\mathrm{Zn} / \mathrm{Al}$ by ion-exchange; PZAC, perindopril intercalated into $\mathrm{Zn} / \mathrm{Al}$ by coprecipitation method.

\section{Conclusion}

A new nanocomposite material was synthesized by intercalating perindopril into $\mathrm{Mg} / \mathrm{Al}$-layered double hydroxide using a simple ion-exchange method. X-ray diffraction patterns suggested that expansion of interlayer spacing to $21.98 \AA$ is due to the size and spatial orientation of perindopril intercalated into the interlayer, when compared with $21.70 \AA$ and $19.90 \AA$ for PZAE and PZAC, respectively. Interaction between the perindopril moiety and the positive charge of the layered double hydroxide inorganic interlayers was supported by FTIR. Loading of perindopril was estimated to be about $36.5 \%, 37.2 \%$, and $33.4 \%(w / w)$ for PMAE, PZAE, and PZAC, respectively, with more thermal stability than its free counterpart. The thermal stability was in the order of PMAE $>$ PZAE $>$ PZAC. Release of perindopril anions into the buffer solution was found to occur in a controlled manner, governed by pseudo-second order kinetics for all the nanocomposites. MTT assay on the Chang cells line show no cytotoxic effect of either $\mathrm{Mg} / \mathrm{Al}$-layered double hydroxide or PMAE, similar to the PZAE and PZAC nanocomposites. The $\mathrm{Mg} / \mathrm{Al}$-layered double hydroxide showed mild ACE inhibitory activity, but surprisingly, Zn/Al-layered double hydroxide show no effect on ACE. The ACE inhibition activity of PMAE was observed to be time-dependent due to controlled release of perindopril from the interlayers of the nanocomposites. Inhibition by PMAE was higher than for PZAE and PZAC, presumably due to controlled release and the cation effect of magnesium.

\section{Acknowledgments}

The authors thank the Ministry of Science Technology and Innovation for funding this project under grant 05-03-101035 NND (Vot 5489100). The author (Samer Hasan) is grateful to Universiti Putra Malaysia for an International Graduate Research Fellowship.

\section{Disclosure}

The authors report no conflicts of interest in this work.

\section{References}

1. Carlino S. The intercalation of carboxylic acids into layered double hydroxides: a critical evaluation and review of the different methods. Solid State Ionics. 1997;98:73-84.

2. Brown G, Brindley GW. Crystal Structures of Clay Minerals and their X-ray Identification. London, UK: Mineralogical Society; 1980.

3. Rives V. Layered Double Hydroxides: Present and Future. New York, NY: Nova Science Publications Inc; 2001.

4. Auerbach SM, Carrado KA, Dutta PK. Handbook of Layered Materials. New York, NY: CRC Press; 2004.

5. Tyner KM, Schiffman SR, Giannelis EP. Nanobiohybrids as delivery vehicles for camptothecin. J Control Release. 2004;95:501-514.

6. Choy JH, Kwak SY, Park JS, Jeong YJ, Portier J. Intercalative nanohybrids of nucleoside monophosphates and DNA in layered metal hydroxide. J Am Chem Soc. 1999;121:1399-1400.

7. Choy JH, Jung JS, Oh JM, et al. Layered double hydroxide as an efficient drug reservoir for folate derivatives. Biomaterials. 2004;25:3059-3064.

8. Oh JM, Park M, Kim ST, Jung JY, Kang YG, Choy JH. Efficient delivery of anticancer drug MTX through MTX-LDH nanohybrid system. J Phys Chem Solids. 2006;67:1024-1027.

9. Choi SJ, Oh JM, Choy JH. Anticancer drug-layered hydroxide nanohybrids as potent cancer chemotherapy agents. J Phys Chem Solids. 2008;69:1528-1532.

10. Zhang H, Zou K, Guo S, Duan X. Nanostructural drug-inorganic clay composites: structure, thermal property and in vitro release of captoprilintercalated MgAl-layered double hydroxides. J Solid State Chem. 2006;179:1792-1801.

11. Li B, He JG, Evans D, Duan X. Inorganic layered double hydroxides as a drug delivery system-intercalation and in vitro release of fenbufen. Appl Clay Sci. 2004;27:199-207.

12. Ambrogi V, Fardella G, Grandolini G, Perioli L, Tiralti MC. Intercalation compounds of hydrotalcite-like anionic clays with antiinflammatory agents, II: uptake of diclofenac for a controlled release formulation. AAPS Pharm Sci Tech. 2002;3:77-82.

13. Ambrogi V, Fardella G, Grandolini G, Perioli L. Intercalation compounds of hydrotalcite-like anionic clays with antiinflammatory agents - I. Intercalation and in vitro release of ibuprofen. Int J Pharm. 2001;220:23-32.

14. Panda HS, Srivastava R, Bahadur D. In-vitro release kinetics and stability of anticardiovascular drugs-intercalated layered double hydroxide nanohybrids. J Phys Chem B. 2009;113:15090-15100.

15. Mohanambe L, Vasudevan S. Anionic clays containing anti-inflammatory drug molecules: comparison of molecular dynamics simulation and measurements. J Phys Chem B. 2005;109:15651-15658.

16. Wang Z, Wang E, Gao L, Xu L. Synthesis and properties of $\mathrm{Mg}_{2} \mathrm{Al}$ layered double hydroxides containing 5-fluorouracil. J Solid State Chem. 2005;178:736-741.

17. Xia SJ, Ni ZM, Xu Q, Hu BX, Hu J. Layered double hydroxides as supports for intercalation and sustained release of antihypertensive drugs. J Solid State Chem. 2008;181:2610-2619.

18. Mohanambe L, Vasudevan S. Anionic clays containing anti-inflammatory drug molecules: comparison of molecular dynamics simulation and measurements. J Phys Chem B. 2005;109:15651-15658.

19. Wei M, Pu M, Guo J, et al. Intercalation of L-dopa into layered double hydroxides: enhancement of both chemical and stereochemical stabilities of a drug through host-guest interactions. Chem Mater. 2008;20: 5169-5180.

20. Kong X, Shi S, Han J, Zhu F, Wei M, Duan X. Preparation of glycy-L-tyrosine intercalated layered double hydroxide film and its in vitro release behavior. Chem Eng J. 2010;157:598-604.

21. Al Ali SHH, Al-Qubaisi M, Hussein MZ, Ismail M. Zainal Z, Hakim MN. Controlled release and angiotensin-converting enzyme inhibitor properties of an antihypertensive drug based on a perindopril erbumine-layered double hydroxide nanocomposite. Int J Nanomedicine. 2012;7:2129-2141.

22. Wei M, Yuan Q, Evans DG, Wang Z, Duan X. Layered solids as a "molecular container" for pharmaceutical agents: L-tyrosine-intercalated layered double hydroxides. J Mater Chem. 2005;15:1197-1203. 
23. Silion M, Hritcu D, Jaba IM, et al. In vitro and in vivo behavior of ketoprofen intercalated into layered double hydroxides. J Mater Sci Mater Med. 2010;21:3009-3018.

24. Cavani F, Trifir'o F, Vaccari A. Hydrotalcite-type anionic clays: Preparation, properties and applications. Catal Today. 1991;11:173-301.

25. Smith BC. Infrared Spectral Interpretation: A Systematic Approach. Boca Raton, FL: CRC Press, 1999.

26. Jiao FP, Chen XQ, Fu ZD, Hu YH, Wang YH. Intercalation of Mg-Al layered double hydroxides by (+)-dibenzoyl-d-tartaric acid: preparation and characterization. J Mol Struct. 2009;921:328-332.

27. Kloprogge JT, Frost RL. Fourier transform infrared and raman spectroscopic study of the local structure of Mg-, Ni-, and co-hydrotalcites. J Solid State Chem. 1999;146:506-515.

28. Macêdo RO, Gomes do Nascimento T, Soares Arago CF, Barreto Gomes AP. Application of thermal analysis in the characterization of anti-hypertensive drugs. J Thermal Anal Cal. 2000;59:657-661.

29. Pascard C, Guilhem J, Vincent M, Remond G, Portevin B, Laubie M. Configuration and preferential solid-state conformations of perindoprilat (S-9780). Comparison with the crystal structures of other ACE inhibitors and conclusions related to structure-activity relationships. $J \mathrm{Med}$ Chem. 1991;34:663-669.

30. Miyata S. Hydrotalcites in relation to composition. Clays Clay Miner. 1980;28:50-56.

31. Oriakhi CO, Farr IV, Lerner MM. Incorporation of poly (acrylic acid), poly (vinylsulfonate) and poly (styrenesulfonate) within layered double hydroxides. J Mater Chem. 1996;6:103-107.

32. Sing KSW. The use of gas adsorption for the characterization of porous solids. Colloids Surf. 1989;38:113-124.
33. Pierotti RA, Rouquerol J. Reporting physisorption data for gas/sloid systems with special reference to the determination of surface area and porosity. Pure Appl Chem. 1985;57:603-619.

34. Khan AI, O'Hare D. Intercalation chemistry of layered double hydroxides: recent developments and applications. J Mater Chem. 2002;12:3191-3198.

35. Hussein MZ, Zainal Z, Yahaya AH, Foo DWV. Controlled release of a plant growth regulator, alpha-naphthalene acetate from the lamella of Zn-Al-layered double hydroxide nanocomposite. J Control Release. 2002;82:417-427.

36. Zhang H, Zou K, Sun H, Duan X. A magnetic organic-inorganic composite: Synthesis and characterization of magnetic 5-aminosalicylic acid intercalated layered double hydroxides. J Solid State Chem. 2005; 178:3485-3493.

37. Dong L, Yan L, Hou WG, Liu SJ. Synthesis and release behavior of composites of camptothecin and layered double hydroxide. J Solid State Chem. 2010;183:1811-1816.

38. Ho YS, Ofomaja AE. Pseudo-second-order model for lead ion sorption from aqueous solutions onto palm kernel fiber. $J$ Hazard Mater. 2006;129:137-142.

39. Masarudin MJ, Yusoff K, Rahim RA, Hussein MZ. Successful transfer of plasmid DNA into in vitro cells transfected with an inorganic plasmid-Mg/Al-LDH nanobiocomposite material as a vector for gene expression. Nanotechnology. 2009;20:045602.

40. Muir KW. Therapeutic potential of magnesium in the treatment of acute stroke. J Stroke Cerebrovasc Dis. 2000;9:257-267.
International Journal of Nanomedicine

\section{Publish your work in this journal}

The International Journal of Nanomedicine is an international, peerreviewed journal focusing on the application of nanotechnology in diagnostics, therapeutics, and drug delivery systems throughout the biomedical field. This journal is indexed on PubMed Central, MedLine, CAS, SciSearch $\AA$, Current Contents ${ } /$ Clinical Medicine,

\section{Dovepress}

Journal Citation Reports/Science Edition, EMBase, Scopus and the Elsevier Bibliographic databases. The manuscript management system is completely online and includes a very quick and fair peer-review system, which is all easy to use. Visit http://www.dovepress.com/ testimonials.php to read real quotes from published authors. 